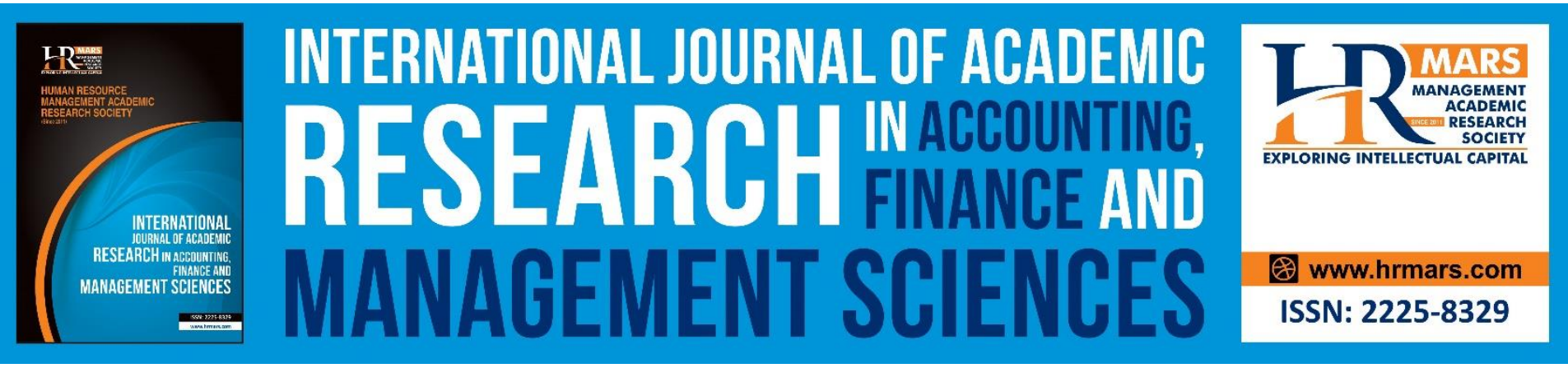

\title{
Customer Satisfaction through Management Accounting Practices in the Hotel Industry
}

Salumah Nain, Rasid Mail, Nelson Lajuni, Stephen Sondoh Jr.

To Link this Article: http://dx.doi.org/10.6007/IJARAFMS/v10-i3/7752

DOI:10.6007/IJARAFMS /v10-i3/7752

Received: 19 October 2020, Revised: 20 November 2020, Accepted: 25 December 2020

Published Online: 29 December 2020

In-Text Citation: (Nain et al., 2020)

To Cite this Article: Nain, S., Mail, R., \& Jr., N. L. S. S. (2020). Customer Satisfaction through Management Accounting Practices in the Hotel Industry. International Journal of Academic Research in Accounting Finance and Management Sciences, 9(4), 510-526.

\section{Copyright: (C) 2020 The Author(s)}

Published by Human Resource Management Academic Research Society (www.hrmars.com)

This article is published under the Creative Commons Attribution (CC BY 4.0) license. Anyone may reproduce, distribute, translate and create derivative works of this article (for both commercial and non-commercial purposes), subject to full attribution to the original publication and authors. The full terms of this license may be seen at: http://creativecommons.org/licences/by/4.0/legalcode

Vol. 10, No. 3, 2020, Pg. 510 - 526

Full Terms \& Conditions of access and use can be found at http://hrmars.com/index.php/pages/detail/publication-ethics 


\title{
Customer Satisfaction through Management Accounting Practices in the Hotel Industry
}

\author{
${ }^{1}$ Salumah Nain, ${ }^{2}$ Rasid Mail, ${ }^{3}$ Nelson Lajuni, ${ }^{4}$ Stephen Sondoh Jr. \\ ${ }^{1}$ SIDMA College, Sabah, ${ }^{2}$ Universiti Malaysia Sabah, ${ }^{3}$ Universiti Malaysia Sabah, ${ }^{4}$ Universiti Malaysia \\ Sabah \\ Email: ${ }^{1}$ salumahphd@gmail.com, ${ }^{2}$ rmail@ums.edu.my, ${ }^{3}$ nelsonl@ums.edu.my, ${ }^{4 j u d e @ u m s . e d u . m y ~}$
}

\begin{abstract}
The role of management accounting practices in enhancing customer satisfaction has often been overlooked by many. Therefore, this study aims to examine the antecedent role of management accounting practices and their influence on customer satisfaction. Non-probability purposive sampling technique was used to identify the respondents among hotel accounting staffs in Malaysia $(N=200)$ to examine the customers' satisfaction through management accounting practices in the hotel industry. The current data is analyzed by utilizing Partial Least Square Structural Equation Modeling (PLS-SEM) using the SmartPLS version 3.0 application. The results indicate that management accounting practices had significant effects on customer satisfaction. The findings provide a better understanding of the antecedent role of management accounting practices and their influence on hotel's customer satisfaction. Limitations and contributions are also discussed to justify the significance of this research.
\end{abstract}

Keywords: Antecedent, Management Accounting Practices, Customer Satisfaction, Hotel

\section{Introduction}

The hotel industry is one of the most dynamic sectors in the world. This sector places its customers as the heartbeat of its operations to deliver the best memorable experience. However, with the changing of times and demands of the new trends in travelling, hotels need to keep up and stay relevant despite the fierce competition in the industry.

The hotels are managing their business in a competitive environment which demand a robust managerial approach by considering both the philosophical and technical aspects of the business process. In running the hotel operation, many traditional approaches and conventional concepts are replaced with technological-based platforms. Thus, to be successful in the market, it is not sufficient to lay focus on attracting new customers only. The managers must also concentrate on retaining existing customers and implementing effective practices to improve customer satisfaction and loyalty. In the hotel industry, customers' satisfaction primarily hooked upon the quality of service. Hence, exploring the influences of Management Accounting Practices (MAPs) on customer satisfaction in the hotel selection is indispensable. 
INTERNATIONAL JOURNAL OF ACADEMIC RESEARCH IN ACCOUNTING, FINANCE AND MANAGEMENT SCIENCES

Vol. 10 , No. 3, 2020, E-ISSN: $2225-8329$ @ 2020 HRMARS

Alternatively, management accounting practices are introduced to companies as these practices can assist in providing relevant and useful information to hotel managers, especially in maintaining companies' sustainability in the competitive global market (Sunarni, 2013). Moreover, Pavlatos and Kostakis (2015) also argued that the new economic environment, which was mainly triggered by the global economic crisis, imposed the need for the adaptation of MAPs in improving organization's performance and profitability (Sunarni, 2013) to address the dynamics of the market. Furthermore, Abdel-Kader and McLellan (2013) claimed that management accounting practices have a significant effect on the performance of an organization. The adoption of management accounting practices is believed to cover different aspects in the organization such as strategic planning, resources, cost control, and operation activities, which have become the dominant approach in managing different aspects of a firm's performance.

Hence, Management Accounting (MA) is one of the operational aspects that gets more attention in handling the new economic environment. In the service industry, such as hotel management, less tangible operational elements are more dominant, such as overhead and labor components, where the MA's managerial potential is more appealing than in other industries. Management accounting concerns with the provision of information within the organization and managers at various organization levels to make better decisions and improve operational efficiency and effectiveness (Drury, 2015).

Moreover, research on the contextual factors as an antecedent of the uptake of MAPs has been considered scarce (Pavlatos \& Paggios, 2009), especially in the Malaysian context. Besides, research on the influence of management accounting practices towards customer satisfaction has been overlooked by many. In specific, research regarding guest satisfaction that translates into the consideration of adopting management accounting practices can improve customer loyalty which is also pivotal to the success of the hospitality business.

In sum, recent developments in cost accounting has allowed for a stronger focus on customer satisfaction, but fewer studies are concentrating explicitly on the relationship between cost and customer satisfaction. Previous literature that investigates the relationship between costs and clients (McNair, Polutnik \& Silvi, 2001; Van Raaij, Vernooij \& Triest, 2003) has only focused on industrial companies but not the service industries. Nevertheless, the relationship between costs and customer satisfaction is far more important in service industries because customer satisfaction determined by customer behavior (Krakhmal, 2006). Therefore, among others, practitioners and researchers are curious about the attributes of MAPs among hoteliers, cause, and causal of its adoption. Thus, this paper presents the antecedent of MAPs on customer satisfaction in the hotel industry.

\section{Literature Review}

\section{Management Accounting Practices}

Management Accounting is concerned with providing information to people within the organization to help them make better decisions and improve the efficiency and effectiveness of existing business operations (Drury, 2015). Hilton and Platt (2011) assert that MA is the process of identifying, measuring, analyzing, interpreting, and communicating information in pursuit of organizational goals. Besides, Macinati and Anessi-Pessina (2014) defined MA as a collection of cost-related managerial practices such as budgeting or product costing.

One of the crucial issues in management accounting is the adoption of management accounting practices in the organization. Moreover, Islam and Kantor (2005) defined MAPs as practices that 
INTERNATIONAL JOURNAL OF ACADEMIC RESEARCH IN ACCOUNTING, FINANCE AND MANAGEMENT SCIENCES

Vol. 10 , No. 3, 2020, E-ISSN: $2225-8329$ @ 2020 HRMARS

make use of existing techniques and tools by management accountants to assist them in providing management accounting information for the manager in doing their managerial function. In that notion, management accounting can be defined as highly complex activities in a strategic context and is considered as one of the critical parts of an organization operation as it reflects broader functionality than its former terms of the bean-counting process, back door function, and many other terms that implied to its traditional roles.

Thus, management accounting refers to transaction processing that gathers and aggregates data in a meaningful manner. Changes in the business environment affect how businesses should be operated, traded, and managed. These changes indirectly affect management accounting's function and task since management accountants have traditionally provided information that facilitates and supports effective and efficient operations and management. Numerous factors have driven business managers to seek new information with consequences for the roles of management accountants. The driving forces to the changing roles of management accountants are globalization, technology, accounting scandals, and corporate trends.

A study by Horngren (1995) found that the focus of cost management should be on decisions and the various cost management techniques, systems, and measurements that spur and help managers to make a wiser economic decision. Burns and Scapens (2000) argued that competitive environment situation, primarily global competition, was most frequently cited in fostering the change in management accounting. However, past studies have presented a few critics on management accounting.

Kaplan (1986) criticized that management accounting is lagging in its development, and Kaplan and Johnson (1987) pointed out that management accounting is not able to innovate. Moreover, Noordin, Zainuddin, Fuad, and Mail (2014) added that traditional management accounting is seen as 'slow' and 'ill-defined' where they found out that traditional management information was less relevant and short-termism in determining the direction of an organization.

Therefore, over these past three decades, there has been a tremendous increase in the number of innovative management accounting practices that developed across a wide range of industries (Pavlatos, 2014; Abdel-Kader \& Luther, 2008). Thus, the terms such as 'strategic management accounting' and 'advance management accounting' have started to become more popular (Nordin et al., 2014). Additionally, contemporary management accounting practices generally refer to advanced management accounting techniques (Chenhall \& Langfield-Smith, 1998).

Notably, there are many studies in the literature that claimed traditional management accounting as a static and limited organizational process. Some claimed that it did not consider the organization's strategic needs, whereby non-monetary information was neglected and did not account for decision making. However, the traditional role of management accounting techniques has been predominantly adopted in most parts of the world for years (Emily et al., 2007), especially in the late 80s, where management accounting techniques started to take up more strategic roles (Simmonds, 1981). This phenomenon is consistent with the development of strategic thinking in business that also took place at about the same timeline. As proclaimed by many, this move is in line with the increase of complexity on how business operated primarily because of global competition and progression in management accounting theory (Zarowin, 1997, Siegel, \& Sorensen, 1999, \& Burns \& Scapens, 2000). They advocate that it enables MA to supplement the changing needs of managers to meet contemporary challenges and competitive environments (Allot, 2000).

Indeed, the increase in the complexity of how the business operates in global competition and 
INTERNATIONAL JOURNAL OF ACADEMIC RESEARCH IN ACCOUNTING, FINANCE AND MANAGEMENT SCIENCES

Vol. 10 , No. 3, 2020, E-ISSN: $2225-8329$ @ 2020 HRMARS

the progression in management accounting theory as well in practice, is proclaimed by many (Burns \& Scapens, 2000; Siegel \& Sorensen, 1999; \& Zarowin, 1997). They advocate that it enables management accounting to supplement the changing needs of managers to meet contemporary challenges and competitive environments (Allot, 2000).

To some researchers, the failure of management accounting to deliver its intended outcome was not due to the environmental factors or weakness in the technique but the failure of the practitioner to utilize the management accounting tools appropriately (Nandan, 2010). Researchers like Drury (1992) advocates that traditional management accounting system has failed to report information that formed the elements of competitive advantage such as quality, reliability, lead times, flexibility, and customer satisfaction. However, these represent the strategic goals of world-class manufacturing companies.

Waweru, Houge, and Uliana (2005) stated that the effect of market economy, intensified competition, globalization, scarce resources, change in the business environment, and accelerating technological changes have driven companies to realize the need to have objectives information and awareness of the need of more detailed cost information. In today's business, managers must continuously ensure that their companies could sustain in the global market. A company must be able to compete nationally and internationally to sustain itself in the market.

Presently, managing today's enterprises has become more challenging due to the rapid growth in the economy. Within a rapidly growing global economic change, managers are required to be more responsive to the changes in the market environment. Such changes accelerated with additional factors such as technological advancement, information and communication technology, political turmoil, economic crisis, the intensity of market competition, and cultural changes, have changed the way businesses are carried out, and enterprises managed. Besides, Gary, Ghosh, Hudick, and Nowacki (2003) stressed that the increasing market competition and uncertainty in the business environment had put significant pressure on managers to make timely and informed business decisions accordingly. Moreover, managers need to be equipped with multiple skills and should be looking for more rigorous support from every aspect of organizational management to deal with the changes in today's economy.

Consequently, several kinds of research have been done in management accounting, especially on its contribution to enhancing customer satisfaction. Though there are plenty of research in management accounting, most of them are focused on the traditional ways of cost control rather than more advanced techniques in measuring customer satisfaction objectives. The role of management accounting in the hospitality sector is considered one of the under-researched areas (Pellinen, 2003). Sevim and Korkmaz (2014) also agreed that only a small number of studies have investigated the use and utilization of management accounting systems among hotels.

Therefore, management accounting practices have progressed to address the need to respond to the changes in the industrial and sectoral environment. The theoretical and practical aspects of MAP have been developed to equip the needs of organizational management in making timely and accurate decision making in enhancing customer satisfaction. As such, this study investigates customer satisfaction through management accounting practices to provide a better understanding of the form of current practices and the related antecedent factors associated with the hotel industry in Malaysia. 
INTERNATIONAL JOURNAL OF ACADEMIC RESEARCH IN ACCOUNTING, FINANCE AND MANAGEMENT SCIENCES

Vol. 10 , No. 3, 2020, E-ISSN: $2225-8329$ @ 2020 HRMARS

\section{Customer Satisfaction}

One of the biggest challenges for the hotel industry is to sustain customer satisfaction. Customer requirements for quality products and services in the tourism industry have become increasingly evident to professionals (Lam \& Zhang, 1999; Yen \& Su, 2004). Many have claimed that customer satisfaction is the starting point to define business objectives such as affects business profitability (Anderson, Fornell, \& Lehmann,1994; Yeung, Ging \& Ennew, 2002; and Luo \& Homburg, 2007). Thus, in this context, positive relationships exist between higher customer's commitments and increase in profit and return rate.

In order to achieve customer satisfaction, it is vital to recognize and anticipate customers' needs and to be able to satisfy them. Enterprises that can rapidly understand and fulfil customers' needs make great profits than those who fail to understand and satisfy their customers (Barsky and Nash, 2003). Moreover, the cost of attracting new customers is higher than the cost of retaining existing ones. Therefore, in order to be successful, managers must concentrate on retaining existing customers by implementing effective policies of customer satisfaction and loyalty.

However, hotels cannot survive without satisfied customers (Chi \& Gursoy, 2009) because customers are the vital driver of a hotel property's financial performance (Kim et al., 2013). Moreover, studies by McNair et al. (2001) and Van Raaij et al. (2003) that investigated the relationship between cost and clients only focused on industrial companies but not service industries. In fact, the relationship between costs and customer satisfaction is far more important in service industries since the costs of providing the service are usually determined by customer behavior (Krakhmal, 2006).

While the literature on management accounting practices notes the importance of customer satisfaction, this study fills a gap in a critical and under-researched area by investigating the relationship between the adoption of management accounting practices and customer satisfaction. This research may help promoting greater diffusion of management accounting practices in the Malaysian hotel industry.

\section{Antecedent Contingency Factors}

Contingency-based research has a long tradition in the field of management accounting (Chapman, 1997; Chenhall, 2003; and Gerding \& Greve, 2004). This theory suggests that an appropriate accounting system's particular features rely upon the specific circumstances in which an organization finds itself (Otley, 1980). Additionally, contingency theory also supports the idea that no universally appropriate accounting system applies equally to all organizations in all circumstances (Otley, 1980, and Emmanuel et al., 1990).

Furthermore, contingency theory explains how an appropriate accounting information system is designed to match the organization structure, technology, strategy, and environment. Hopwood (1976) had pointed out that the design of a management accounting system and the design of an organizational structure are inseparable and interdependent, although this vital observation has been neglected over the years.

Thus, the contingency-based approach assumes that management accounting systems are adopted to help managers achieve desired company outcomes or goals. As mentioned above, contingency theory explains how an appropriate accounting information system is designed to match the organization structure, technology, strategy, and environment. Therefore, it is presumed that organizations operate in an open system, at the same time, these organizations also concern about their goals and how they respond to external and internal pressures. 
Haldma and Laats (2002) categorized the contingencies into two general groups, which are external and internal factors. External factors indicate the features of the external environment at the level of business and accounting. Hence, major external factors that are examined at the company level in management accounting and control (including cost accounting) research are external environment (Emmanuel et al., 1990; Khandwalla, 1977; Chapman, 1997; Hartmann, 2000) and national culture.

On the contrary, the foremost common internal factors that are examined concerning management accounting are organizational size (Khandwalla, 1972; Bruns et al., 1975; Merchant, 1981), technology (Khandwalla, 1977; Merchant, 1984; Dunk, 1992) and companies' strategies (Miles, Snow, \& Coleman, 1978; Govindarajan \& Gupta, 1985; Simons, 1987; Chenhall \& Morris, 1995).

Therefore, to explain the diversity of management accounting practices, there is a need for organization to adopt contingency theory to demonstrate how specific aspects of an accounting system are associated with various contextual variables such as size, competition, and cost structure (Emmanuel et al., 1990).

Based on the discussion above, three antecedent contingency factors were examined in this study, by adopting the underlying theory to explain the current research. The three antecedent contingency factors are the intensity of market competition (IMC), technology (TECH), and hotel size (HS). These factors are believed to contribute to the adoption of management accounting practices in the Malaysian hotel industry.

\section{Framework And Hypotheses Development}

The theoretical framework shown below was developed based on the discussed literature reviews and adopted from the previous study. The research framework is shown in Figure 1, followed by four hypotheses of the study.

$\mathrm{H}_{1}: \quad$ IMC positively influences MAPs.

$\mathrm{H}_{2}$ : TECH positively influences MAPs.

$\mathrm{H}_{3}$ : $\quad$ HS positively influences MAPs.

$\mathrm{H}_{4}$ : $\quad$ MAPs positively influence $\mathrm{CS}$.

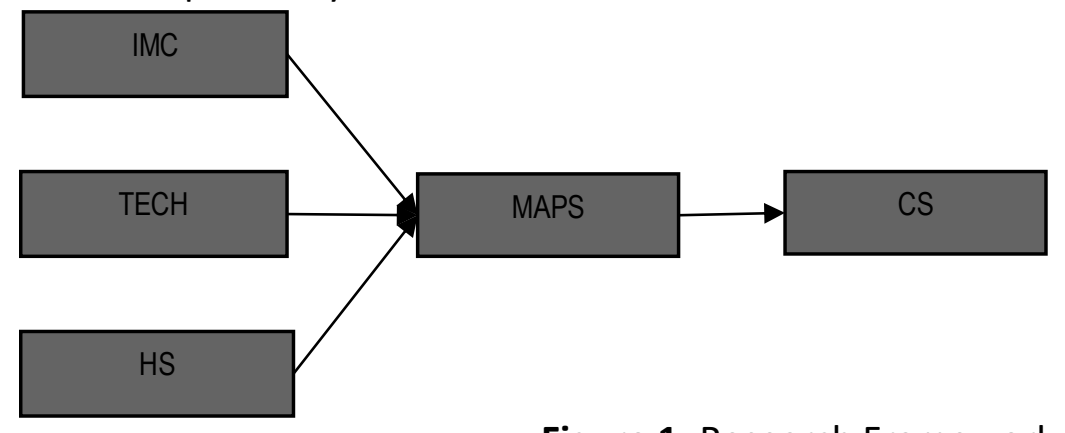

Figure 1: Research Framework

\section{Research Methodology}

A non-probability purposive sampling technique was adopted to verify that the collected data were valid and to ensure the sample characteristics corresponded to the nature of the study. For this study, the questionnaire was used as an instrument to gather relevant information from the respondents. The scaling technique required respondents to indicate a degree of disagreement with 
INTERNATIONAL JOURNAL OF ACADEMIC RESEARCH IN ACCOUNTING, FINANCE AND MANAGEMENT SCIENCES

Vol. 10, No. 3, 2020, E-ISSN: 2225-8329 ๔ 2020 HRMARS

each series of statements. A Likert 5-point scale was used to differentiate the degree of agreement and disagreement. The target population for this study was pooled from hotels listed under the Ministry of Tourism, Arts, and Culture of Malaysia (hereafter MOTAC) regardless of their star rating. The MOTAC directory used as a sampling frame due to the importance of making sure that the samples adequately represent the intended target population to which the hypothesis testing results are generalized (Van der Stede \& Merchant, 2007).

Sample size estimation was determined using $G *$ power 3.0 analysis (Faul et al., 2007). By using G-Power Analysis software, with the effect size of $f$-square 0.15 , $\alpha$ error pro 0.05 , power $\mathrm{Gf} 0.95$ with three tested predictors. One hundred nineteen respondents needed as the minimum sample for this study. Data were collected using a mail and field survey. Three hundred eighty-four (384) questionnaires were sent out, and within six months, only 217 hotels had replied which represent 56.5 percent response rate. Out of 217 questionnaires returned, 17 were rejected, leaving 200 questionnaires usable for the analysis (52 percent response rate). According to Smith (2003), a response rate above 25 percent in accounting research is considered sufficient for statistical analysis and inferences. Figure 1 illustrates the research framework that contains statements of three variables investigated. The variables are examined using multiple items (Hayduk \& Littvay 2012), and the data was then analyzed using SmartPLS 3.3.2 (Ringle et al., 2015) to assess the hypotheses.

\section{Data Analysis And Results}

Table 1 presents the profile of the participating hotels in the current study. As can be seen from Table 1 , majority of the respondents are from 3-star hotel, private company management status, and city hotel. Half of the participating hotels are from the west region (Sabah, Sarawak, and Federal Territory of Labuan). Moreover, majority of the participating hotels have the number of beds ranging from 1 to 100 beds, and the number of rooms ranges below 50 rooms. Hotel size was measured using the number of rooms adopted from Kasimu, Zaiton, and Hassan (2012), in which hotels having more than 100 rooms are considered as large and those with less than 100 rooms are considered small. The current study reveals that 62.5 percent of the hotels are categorized as small size hotels.

Table 1: Demographic data of hotels that participated in the survey ( $N=200)$

\begin{tabular}{lll}
\hline Categories & N & Percent \\
\hline 5 - stars & 10 & 5.0 \\
4- stars & 25 & 12.5 \\
3 - stars & $\mathbf{7 2}$ & $\mathbf{3 6 . 0}$ \\
2 - stars & 41 & 20.5 \\
1 - star & 19 & 15.5 \\
Others & 33 & 25.5 \\
\hline Region Area & & \\
\hline Central & 30 & 13.8 \\
Southern & 23 & 10.5 \\
East Coast & 17 & 7.8 \\
Northern & 33 & 15.2 \\
West & $\mathbf{1 1 4}$ & $\mathbf{5 2 . 5}$ \\
\hline No of beds & & \\
\hline
\end{tabular}


INTERNATIONAL JOURNAL OF ACADEMIC RESEARCH IN ACCOUNTING, FINANCE AND MANAGEMENT SCIENCES

Vol. 10, No. 3, 2020, E-ISSN: $2225-8329$ @ 2020 HRMARS

\begin{tabular}{lll}
\hline $\mathbf{1 - 1 0 0}$ & $\mathbf{8 5}$ & $\mathbf{4 2 . 5}$ \\
$100-200$ & 55 & 27.5 \\
$200-300$ & 24 & 12.0 \\
Over 300 & 36 & 18.0 \\
\hline No of rooms & & \\
\hline $\mathbf{1 - 5 0}$ & $\mathbf{7 8}$ & $\mathbf{3 9 . 5}$ \\
$50-100$ & 46 & 23.0 \\
Over 100 & 75 & 49.5 \\
\hline Company management status & & \\
\hline Private company & $\mathbf{1 8 5}$ & $\mathbf{9 2 . 6}$ \\
Member of a national chain & 7 & 3.5 \\
Member of a multinational chain & 8 & 4.0 \\
\hline Type of hotel & & \\
\hline Resort & & 8.0 \\
City hotel & 16 & $\mathbf{7 2 . 5}$ \\
Others & $\mathbf{1 4 5}$ & 13.5 \\
\hline Hotel size (No of room) & 39 & $\mathbf{6 2 . 5}$ \\
\hline Small (Less than 100 rooms) & & 37.5 \\
Large (more than 100 rooms) & $\mathbf{1 2 5}$ & \\
\hline
\end{tabular}

\section{Measurement Model}

Table 2 demonstrates the findings of construct reliability $(C R)$ and convergent validity testing. The results validate that the constructs (or variables under investigation) to have high internal consistency (Roldán \& Sánchez-Franco, 2012) and sufficient average variance extracted (AVE) to corroborate the convergent validity (Hair et al., 2017). All indicators measuring each construct achieve good loadings value higher than the threshold value of 0.708 , as advocated by Hair et al. (2017).

The composite reliability (CR) values of 0.973 (CS), 1.00 (HOTEL SIZE), 0.934 (IMC), 0.972 (MAPs), and 0.823 (HOTEL SIZE) implies that these constructs possess high internal consistency. In a similar vein, these constructs also indicate that convergent satisfaction validity with the average variance satisfaction (AVE) value for respective constructs is higher than the threshold value of 0.5 , demonstrating that the indicators explain more than $50 \%$ of the constructs' variances. 
INTERNATIONAL JOURNAL OF ACADEMIC RESEARCH IN ACCOUNTING, FINANCE AND MANAGEMENT SCIENCES

Vol. 10 , No. 3, 2020, E-ISSN: 2225-8329 @ 2020 HRMARS

Table 2: Measurement Model Assessment

\begin{tabular}{|c|c|c|c|c|c|c|}
\hline Construct & Item & Loadings & CA & CR & AVE & $\begin{array}{c}\text { Convergent } \\
\text { Validity }\end{array}$ \\
\hline \multirow[t]{2}{*}{ CS } & CS1 & 0.972 & 0.944 & 0.973 & 0.947 & Yes \\
\hline & CS2 & 0.974 & & & & \\
\hline HOTELSIZE & SizeRoom & 1.000 & 1.000 & 1.000 & 1.000 & Yes \\
\hline \multirow[t]{6}{*}{ IMC } & IMC1 & 0.820 & 0.915 & 0.934 & 0.701 & Yes \\
\hline & IMC2 & 0.774 & & & & \\
\hline & IMC3 & 0.841 & & & & \\
\hline & IMC4 & 0.881 & & & & \\
\hline & IMC5 & 0.851 & & & & \\
\hline & IMC6 & 0.853 & & & & \\
\hline \multirow[t]{30}{*}{ MAPs } & $A B C 1$ & 0.751 & & & & \\
\hline & $A B C 2$ & 0.766 & & & & \\
\hline & $A B C 3$ & 0.706 & & & & \\
\hline & $A B C 4$ & 0.784 & & & & \\
\hline & $A B C 5$ & 0.792 & & & & \\
\hline & $A B C 6$ & 0.753 & & & & \\
\hline & BEP1 & 0.649 & & & & \\
\hline & BEP2 & 0.561 & & & & \\
\hline & BEP3 & 0.651 & & & & \\
\hline & $\mathrm{BNCH} 1$ & 0.774 & & & & \\
\hline & $\mathrm{BNCH} 2$ & 0.702 & & & & \\
\hline & $\mathrm{BNCH} 3$ & 0.704 & & & & \\
\hline & $\mathrm{BNCH} 4$ & 0.650 & & & & \\
\hline & BUE1 & 0.560 & & & & \\
\hline & BUE2 & 0.611 & & & & \\
\hline & BUR1 & 0.555 & & & & \\
\hline & BUR2 & 0.562 & & & & \\
\hline & CVP1 & 0.718 & & & & \\
\hline & CVP2 & 0.645 & & & & \\
\hline & CVP3 & 0.642 & & & & \\
\hline & CVP4 & 0.666 & & & & \\
\hline & $\mathrm{SC} 1$ & 0.745 & & & & \\
\hline & SC2 & 0.765 & & & & \\
\hline & SC3 & 0.732 & & & & \\
\hline & SC4 & 0.691 & & & & \\
\hline & TC1 & 0.790 & & & & \\
\hline & TC2 & 0.767 & & & & \\
\hline & TC3 & 0.779 & & & & \\
\hline & TC4 & 0.726 & & & & \\
\hline & TC5 & 0.745 & & & & \\
\hline
\end{tabular}


INTERNATIONAL JOURNAL OF ACADEMIC RESEARCH IN ACCOUNTING, FINANCE AND MANAGEMENT SCIENCES

Vol. 10, No. 3, 2020, E-ISSN: $2225-8329$ @ 2020 HRMARS

\begin{tabular}{lllllll} 
& TC6 & 0.707 & & & & \\
& TC7 & 0.791 & & & & \\
& TC8 & 0.799 & & & & \\
\hline TECH & TC9 & 0.780 & & & \\
& TECH1 & 0.627 & 0.712 & 0.823 & 0.540 & Yes \\
& TECH2 & 0.700 & & & \\
& TECH3 & 0.800 & & & \\
& TECH4 & 0.799 & & & & \\
& & & & & \\
\end{tabular}

BUE3, BUR3 and BUR4 items were deleted due to poor loadings Composite Reliability <.708 (Hair et al., 2010 and Hair et al., 2014)

\section{Discriminant Validity}

Table 3 displays the HTMT criterion to evaluate discriminant validity (Ringle, Wende and Will, 2020). In assessing discriminant validity, this study applies Henseler's (2015) heterotrait-monotrait ratio of correlations criterion. The result specifies that discriminant validity is well-established at HTMT0.85 (Diamantopoulos \& Siguaw, 2006), which implies that the discriminant validity issue is of no concern. The findings indicated that it is appropriate to proceed with the structural model assessment to test the study's hypotheses, as there is no issue of multi-collinearity between items loaded on different constructs in the outer model.

Table 3: HTMT Criterion

\begin{tabular}{l|ccccc}
\hline & CS & HOTELSIZE & IMC & MAPS & TECH \\
\hline CS & & & & & \\
HOTELSIZE & 0.169 & & & & \\
IMC & 0.275 & 0.167 & & & \\
MAPs & 0.498 & 0.225 & 0.533 & & \\
TECH & 0.506 & 0.255 & 0.451 & 0.577 & \\
\hline
\end{tabular}

Criteria: Discriminant validity is established at HTMT0.85

\section{Structural Model Assessment}

Table 4 demonstrates the assessment of the path coefficient, which is represented by Beta values for each path relationship. A 5000-bootstrap resampling of data was conducted to examine the hypotheses (Hair et al., 2017). The results for direct effects indicate that the intensity of market competition (IMC) and technology (TECH) have a positive influence on the uptake of MAPs. On the contrary, hotel size (HS) shown to have contradicted results on the adoption of MAPs.

Table 4 depicts the path coefficients assessment. The results indicate that three out of the four proposed relationships are significant. Specifically, the study found support for $\mathrm{H}_{1}$ (IMC $\rightarrow$ MAPS, $\beta=$ $0.380, p<0.001, \mathrm{LLCl}=0.232, \mathrm{ULCl}=0.509), \mathrm{H}_{2}(\mathrm{TECH} \rightarrow \mathrm{MAPS}, \beta=0.335, \mathrm{p}<0.001, \mathrm{LLCl}=0.183$, $\mathrm{ULCl}=0.461)$, and $\mathrm{H}_{4}$ (MAPS $\left.\rightarrow \mathrm{CS}, \beta=0.487, \mathrm{p}<0.001, \mathrm{LLCl}=0.366, \mathrm{ULCl}=0.596\right)$. These findings advocate past studies conducted by Nair (2017) on the relationship between IMC and MAPs, Azudin and Mansor (2018) on the relationship between TECH and MAPs and Allot (2000) on the relationship between MAPs and CS respectively. Nonetheless, this study did not find support for $\mathrm{H}_{3}$. This finding 
INTERNATIONAL JOURNAL OF ACADEMIC RESEARCH IN ACCOUNTING, FINANCE AND MANAGEMENT SCIENCES

Vol. 10, No. 3, 2020, E-ISSN: 2225-8329 @ 2020 HRMARS

corroborates with Duncan and Malini (2016) who also did not find any significant relationship between HS and MAPs in their study.

Table 4: Path Coefficients Assessment

\begin{tabular}{lccccccc}
\hline & Beta & S.E. & t-value & p-value & LLCI & ULCI & Decision \\
\hline H1 : IMC -> MAPs & 0.380 & 0.072 & 5.307 & 0.000 & 0.232 & 0.509 & Supported \\
\hline H2 : TECH -> MAPs & 0.335 & 0.073 & 4.617 & 0.000 & 0.183 & 0.461 & Supported \\
\hline H3 : HS -> MAPs & 0.094 & 0.055 & 1.700 & 0.090 & -0.024 & 0.197 & Not Supported \\
\hline H4 : MAPs -> CS & 0.487 & 0.060 & 8.157 & 0.000 & 0.366 & 0.596 & Supported \\
\hline
\end{tabular}

Path Coefficient 0.01, 0.05 (Hair et al. 2017)

Lateral Collinearity: WIF 3.3 of higher (Diamantopoulos \& Siguaw, 2006)

Table 5 displays the quality of the model. $\mathrm{H}_{1}$ (IMC) and $\mathrm{H}_{2}(\mathrm{TECH})$ shown to carry moderate effect size $\mathrm{f}^{2}$ on the MAPs ( 0.201 and 0.153 , respectively). On the other hand, $\mathrm{H}_{4}$ (MAPs) found to pose a substantial effect size $f^{2}$ on customer satisfaction (CS) (0.310) (Cohen, 1988). The coefficient of determination represented by $\mathrm{R}^{2}$, which explains whether the intensity of market competition (IMC) and technology (TECH) could explain management accounting practices, indicates moderate effect (Chin, 1998). The $R^{2}$ value is 0.237 , suggesting that the antecedents (IMC and TECH) can explain moderately towards MAPs. Meanwhile, The $\mathrm{R}^{2}$ value for $\mathrm{CS}$ is 0.384 , signifying that the MAPs could explain CS substantially.

Furthermore, multi-collinearity between indicators are also assessed. All indicators for variables satisfy the VIF values, and they are consistently below the threshold value of 5.0 (Hair et al., 2014) and 3.3 (Diamantopoulos \& Siguaw, 2006). Therefore, it can be concluded that collinearity issues do not reach critical levels in any of the variables; therefore, there is no issue with estimating the PLS path model. The predictive relevant values of all exogenous (independent) variables towards endogenous (dependent) variable were larger than 0 , indicating that the antecedent variables (IMC, TECH, HS) could predict the MAPs and CS, as presented by $Q^{2}$ using blindfolding procedure (Hair et al., 2017).

Table 5: Model Quality Assessment

\begin{tabular}{lcccc}
\hline \multicolumn{1}{c}{ Direct Effect } & $\mathbf{f}^{\mathbf{2}}$ & $\mathbf{R}^{\mathbf{2}}$ & $\mathbf{V I F}$ & $\mathbf{Q}^{\mathbf{2}}$ \\
\hline $\mathrm{H}_{1}:$ IMC $->$ MAPs & 0.201 & 0.237 & 1.166 & 0.179 \\
$\mathrm{H}_{2}:$ TECH $->$ MAPs & 0.153 & & 1.193 & \\
$\mathrm{H}_{3}:$ HS $->$ MAPs & 0.013 & & 1.057 & \\
$\mathrm{H}_{4}:$ MAPs $->$ CS & 0.310 & 0.384 & 1.000 & 0.221 \\
\hline
\end{tabular}

$\mathrm{R}^{2} \geq 0.26$ consider Substantial (Cohen, 1989)

$f^{2} \geq 0.26$ consider Substantial (Cohen, 1989)

$\mathrm{Q}^{2} \geq 0.00$ consider Large (Hair, 2017)

\section{Conclusion}

This study highlights the roles of antecedent contingency factors towards the use of Management Accounting Practices (MAPs) which proven to have a significant effect on the hotel's customer satisfaction. The current research reveals that the intensity market competition and technology to 
INTERNATIONAL JOURNAL OF ACADEMIC RESEARCH IN ACCOUNTING, FINANCE AND MANAGEMENT SCIENCES

Vol. 10, No. 3, 2020, E-ISSN: 2225-8329 @ 2020 HRMARS

have moderate effect on the adoption of Management Accounting Practices. Surprisingly, in the report, the antecedent of hotel size shows an insignificant correlation between hotel size and the acceptance of accounting standards for management. This suggests that the hotel industry in Malaysia needs to adopt management accounting practices, regardless of the hotel scale (large or small).

The analysis involved a survey data of 200 hotel accounting staffs in Malaysia, which revealed that the management accounting practices' adoption is highly significant in influencing the hotels' customer satisfaction. Specifically, this is consistent with Mubiri's study (2016) that one of hotels' key techniques to improve customer loyalty is benchmarking (MAPs). The hierarchical cost level helps managers to consider cost causation and improve decision-making. Activity-based costing (MAPs) also helps managers understand which consumers are profitable and which do not contribute to improved profitability (Dalci et al., 2010).

In addition, by using management accounting practises, the hotel can monitor customer demands and what action other hotels have taken on these demands. The estimates made under the accounting practises of management show that certain customer groups are unprofitable. Barsky and Nash (2003) have shown that businesses that easily understand and meet the needs of consumers make higher profits than those that struggle to understand and satisfy their customers.

Hence, the main limitation is the survey questions related to the hotel ownership and star rating. Each of the individual hotels has its own private and confidential policy. Hotel's information for instance annual sales, has to be kept strictly private and confidential by the employees and shall not be reported except for certain mandatory reporting required. Yet, some hotels are adhering to the same policy due to the ownership resulting in secrecy, quality assurance, and performance.

This study contributes to the understanding of management accounting practices in service industries through the development of a model that allows establishing a direct relationship between antecedent of management accounting practices and the influences of MAPs in generating customer satisfaction. By assessing this model in the case of the Malaysian hotel industry, it corresponds to the calls for more study on the hospitality business (Collini, 2006; Krakhmal, 2006). Moreover, this finding may also contribute to the Malaysian Association Hotels (MAH) for enlighten them on information about MAPs. Moreover, hotel managers can introduce various advertising schemes or promotions to draw more profitable customers during different seasons. The hotel can draw low-profit customer groups during a low season and can have high-income groups at peak times (Dalci et al., 2010).

Furthermore, recent literature developments in cost accounting has seen a stronger focus on the customer, but studies concentrating on the relationship between cost and customer satisfaction has been overlooked, particularly in the Malaysian context. In fact, the relationship between costs and customer satisfaction is far more important in service industries because customer satisfaction determined by customer behavior (Krakhmal, 2006). Thus, this issue is suggested for further investigation in the future research.

One worth mentioning problem for further investigation is to investigate other antecedents of MAPs such as booking and payment systems in the hotel industry, and the MAPs as a mediating influence on the firm performance of hotels are also recommended for future research. Given the findings and discussions, further investigation by applying multi-group analysis is also recommended to establish differences of effects between groups, such as hotel type, hotel size, or between regions.

Nevertheless, the hotel industry will continue to be affected by disruptors, for instance, Airbnb, Home Cation, or homestay besides fierce competition among hotels itself due to the influx of new 
INTERNATIONAL JOURNAL OF ACADEMIC RESEARCH IN ACCOUNTING, FINANCE AND

MANAGEMENT SCIENCES

Vol. 10 , No. 3, 2020, E-ISSN: 2225-8329 ๔ 2020 HRMARS

hotels in Malaysia. At the same time, competition among hospitality industry players is becoming more intense, creative, and innovative to attract new and existing travelers. Therefore, the hotel industry needs to identify and utilize its success factors and work forwards to improve their business model with effective management accounting practices to ensure retention and loyalty of existing customers while also attracting the new ones, and always ready to stand out from the endless fierce competition.

\section{References}

Abdel-Kader, M., \& Luther, R. (2006). IFAC's Conception of the Evolution of Management Accounting: A Research Note. Advances in Management Accounting, Vol. 15, pp. 229-247.

Abdel-Kader, M., \& Luther, R. (2008). The impact of firm characteristics on management accounting practices: A UK-based empirical analysis. British Accounting Review, 40(1), 2-27.

Adler, R. W., Everett, A. M., Waldron, M. (2000). Advanced management accounting techniques in Manufacturing: Utilization, Benefits, and Barriers to Implementation. Accounting Forum, 24(2).

Ahmad, K. (2013). The Adoption of Management Accounting Practices in Malaysian Small and Medium-Sized Enterprises. Asian Social Science, 10(2), 236-249.

Ahmad, K., \& Zabri, S. M. (2012). The Uptake of Management Accounting Practices Among Malaysian Firms In the SMEs Sector. Proceedings International Conference of Technology Management, Business And, 518-533.

Ahmad, N. S. M., \& Leftesi, A. (2014). An Exploratory Study of the Level of Sophistication of Management Accounting Practices in Libyan Manufacturing Companies. International Business Research, 2(2), 1-10.

Ayed, A. M., Eddine, H. C. A. (2015). The impact of advanced management accounting techniques on the performance. Case of Malaysia. Middle East Journal of Business, 4(1).

Allot, A. (2000). Management Accounting Change: The Chartered Institute of Management Accountant (CIMA). The Institute of Management Accountant (CIMA).

Anderson, E. W., Fornell, C., \& Lehmann, D. R. (1994). Customer Satisfaction, Market Share and Profitability. Journal of Marketing. 56(July): 53-66.

Atkinson, A. A., Waterhouse, J. H., \& Wells, R. B. (1997). A stakeholder approach to strategic performance measurement. Sloan Management, 38(3), 25.

Aziz, A. M. (2012). Strategic Role of Strategic Management Accounting Towards Enhancing SMEs Performance in Iraq.

Azudin, A., \& Mansor, N. (2018). Management accounting practices of SMEs: The impact of organizational DNA, business potential and operational technology. Asia Pacific Management Review, 23(3), 222-226.

Broadbent, J. (1992). Change in organizations: A case study of the use of accounting information in the NHS. The British Accounting Review, 24(4), 343-367.

Burns, J., \& Scapens, R. W. R. (2000). Conceptualizing management accounting change: An institutional framework. Management Accounting Research, 11(1), 3-25.

Chenhall, R. H. (2003)," Management control systems design within its organizational context: findings from contingency-based research and directions for the future," Accounting, Organizations and Society, 28(2), 127-168.

Chenhall, R. H., Langfield-Smith, K., Chenhll, R. H., Langfield-Smith, K., Chenhall, R. H., LangfieldSmith, K., ... Langfield-Smith, K. (1998). Adoption and benefits of management accounting 
INTERNATIONAL JOURNAL OF ACADEMIC RESEARCH IN ACCOUNTING, FINANCE AND

MANAGEMENT SCIENCES

Vol. 10, No. 3, 2020, E-ISSN: $2225-8329$ ๑ 2020 HRMARS

practices: An Australian study. Management Accounting Research, 9(1), 1-19.

Cohen, J. (1988). Statistical power analysis for the behavioral sciences (2nd ed.). Hillsdale, NJ: Lawrence Earlbaum Associates.

Chin, W. W. (1998). Issues and opinion on structural equation modeling. MIS Quarterly, March, viixvi.

Diamantopoulos, A., \& Siguaw, J. A. (2006). Formative versus reflective indicators in organizational measure development: A comparison and empirical illustration. British Journal of Management, 17(4), 263-282.

Drury, C. (2015). Management and Cost Accounting. $9^{\text {th }}$ Edition. Cengage Learning EMEA.

El-Ebaishi, M., Karbhari, Y., \& Naser, K. (2003). Empirical evidence on the use of management accounting techniques in a sample of Saudi manufacturing companies. International Journal of Commerce and Management, 13(2), 74-101.

El-Shishini, H. M. (2017). The Use of Management Accounting Techniques at Hotels in Bahrain. Review of Integrative Business and Economics Research, Vol. 6, no. 2, pp.64-77.

Emmanuel, C., Otley, D., \& Merchant, K. (1990). Accounting for management control. In Accounting for Management Control.

Erik M. Van Raaij, Maarten J.A. Vernooij, Sander Van Triest. (2003). The implementation of customer profitability analysis: A case study. Industrial Marketing Management. (32) $573-583$.

Faul, F., Erdfelder, E., Lang, A - G., \& Buchner, A. (2007). G*Power 3. A flexible statistical power analysis program for the social, behavioral, and biomedical sciences. Behavior Research Methods. 39, 175 - 191.

Fowler, M. (2010). Management accounting education: has the gap closed? Paper presented at the 4th New Zealand Management Accounting Conference, University of Waikato, New Zealand. November.

Gomes, Hair, J. F., Black, W. C., Babin, B. J., \& Anderson, R. (2010). Multivariate data analysis. Upper Saddle River, NJ: Pearson/Prentice Hall.

Hair, J. F., Hult, G. T. M., Ringle, C. M. \& Sarstedt, M. (2014). A Primer on Partial Least Squares Structural Equation Modeling (PLS-SEM). Thousand Oaks, California: Sage Publications.

Hair, J. F., Hult, G. T. M., Ringle, C. M., Sarstedt, M., \& Thiele, K. O. (2017). Mirror, mirror on the wall: A comparative evaluation of composite-based structural equation modeling methods. Journal of the Academy of Marketing Science, 45, 616-632.

Haldma, T., \& Laats, K. (2002). Contingencies influencing the management accounting practices of Estonian manufacturing companies. Management Accounting Research, 13(4), 379-400.

Hayduk, L.A., \& Littvay, L. (2012). Should researchers use single indicators, best indicators, or multiple indicators in structural equation models? BMC Medical Research Methodology.12(159).

Henseler, J., Ringle, C. M., \& Sarstedt, M. (2015). A new criterion for assessing discriminant validity in variance-based structural equation modeling. Journal of the academy of marketing science, 43(1), 115-135.

Hilton, R., \& Platt, D. (2013). Managerial accounting: creating value in a dynamic business environment.

Hopwood, A. (1990). Accounting and organization change. Accounting, Auditing, and Accountability Journal, 3(1), 7-17.

Horngren, C. (2009). Cost accounting: A managerial emphasis, 13/e.

Johnson, H. T., \& Kaplan, R. S. (1987). The Rise and Fall of Management Accounting. IEEE Engineering 
INTERNATIONAL JOURNAL OF ACADEMIC RESEARCH IN ACCOUNTING, FINANCE AND

MANAGEMENT SCIENCES

Vol. 10 , No. 3, 2020, E-ISSN: $2225-8329 @ 2020$ HRMARS

Management Review, 15(3), 36-44.

Joshi, P. L. (2001). The international diffusion of new management accounting practices: The case of India. Journal of International Accounting, Auditing, and Taxation, 10(1), 85-109.

Kaplan, R. S. (1986). The role of empirical research in management accounting. Accounting, Organizations and Society, 11(4-5), 429-452.

Kasimu, A. B., Zaiton, S. B. \& Hassan, H. (2012). Hotels Involvement in Sustainable Tourism Practices in Klang Valley, Malaysia. International Journal of Economics and Management. 6(1). 21 - 34.

Khandwalla, P. (1972). The Effects of Different Types of Competition on the Use of Management controls. Journal of Accounting Research, 275-285.

Krakhmal, V. (2006). Customer profitability accounting in the context of hotels, in P. Harris e M. Mongiello (Eds.). Accounting and Financial Management, Developments in the International Hospitality Industry (pp.188-210). Oxford: Butterworth-Heinemann.

Luo, X., \& Homburg, C. (2007). Neglected outcomes of customer satisfaction. Journal of Marketing, 71(2): 133-149.

Loo, S. C., Nor Aziah, A. K., \& Badriyah, M. (1996). Are management accounting systems in Malaysia outmoded? Singapore Management Review, 18(1), 55-67.

Duncan, M. S., \& Malini, N. (2016). Best practices of sales force compensation within small, to medium sized enterprises: The metrics associated with performance appraisal. The Association of Collegiate Marketing Educators, 123

Nair, S. (2017). Factors affecting management accounting practices in Malaysia.

Noordin, R., Zainuddin, Y., Fuad, C., \& Mail, R. (2014). Strategic management accounting: state-ofthe-art. Malaysian Journal of Business and Economics, 1(June), 47-71.

Otley, D. T. (1980), The contingency theory of management accounting: achievement and prognosis," Accounting, Organizations and Society, 5(4), 413-428.

Pavlatos, O., \& Paggios, I. (2009). Management accounting practices in the Greek hospitality industry. Managerial Auditing Journal, 24(1), 81-98. Phadoongsitthi, M. (2003). The role of managerial accounting in emerging economies: An empirical study of Thailand (Vol. 1).

Phadoongsitthi, M. (2003). The role of managerial accounting in emerging economies: An empirical study of Thailand (1).

Pierce, B. (1998). Management Accounting Practices in Ireland - The Preparers' Perspective. Research Paper Series.

Oliveira, E., Silva, C., Campelo, K., \& Silva, A. (2008). Utilização da gestão de custos para tomada de decisão: um estudo em hotéis de Porto de Galinhas no município de Ipojuca-PE. Paper presented at the 180 Congresso Brasileiro de Contabilidade, Brasil. August.

Rattanaporn, S., Komaratant, D., Cheniam, S., \& Bailes, J. (2000). Management accounting practices of Thai manufacturing companies - Google Search. Proceedings of 12th Asia-Pacific Conference on International Accounting Issues, Beijing, October.

Ringle, C., Wende, S., \& Will, A. (2020). SmartPLS 3.2.9. Retrieved from http://www.smartpls.com

Roldán, J. L., \& Sánchez-Franco, M. J. (2012). Variance-based structural equation modeling: Guidelines for using partial least squares. In M. Mora, O. Gelman, A. L. Steenkamp, \& M. Raisinghani (Eds.), Research methodologies, innovations and philosophies in software systems engineering and information systems (pp. 193-221). Hershey, PA: IGI Global.

Sainaghi, R., Phillips, P., \& Corti, V. (2013). Measuring hotel performance: Using a balanced scorecard perspectives' approach. International Journal of Hospitality Management, 34, 150-159. 
INTERNATIONAL JOURNAL OF ACADEMIC RESEARCH IN ACCOUNTING, FINANCE AND

\section{MANAGEMENT SCIENCES}

Vol. 10, No. 3, 2020, E-ISSN: 2225-8329 @ 2020 HRMARS

Sunarni, C. W. (2013). Management Accounting Practices and The Role of Management Accountant: Evidence from Hotel throughout Yogyakarta, Indonesia. Review of Integrative Business and Economics Research, 2(2), 616-626.

Tuanmat, T. Z., \& Smith, M. (2011). Changes in management accounting practices in Malaysia. Asian Review of Accounting, 19(3), 221-242.

Uyar, A., \& Professor, A. (2010). Cost and Management Accounting Practices. Eurasian Journal of Business and Economics, 3(6), 113-125.

Wirm, A., Van Der Stede, K. A. M. (2007). Management Control Systems: Performance Measurement, Evaluation and Incentives. $2^{\text {nd }}$ Edition.

Xydias-lobo, M., Tilt, C., \& Forsaith, D. (2004). The Future of Management Accounting : A South Australian Perspective. In JAMAR (Vol. 2).

Yeung, M. C. H., Ging, L., \& Ennew, C. T. (2002). Customer satisfaction and profitability. A reappraisal of the nature of the relationship. Journal of Targeting. Measurement and Analysis for Marketing. 11(1): $24-33$. 